\begin{tabular}{|c|c|c|}
\hline()$_{\substack{\text { SilRT } \\
\text { invivensitesi }}}^{(j)}$ & $\begin{array}{c}\text { Türkiye Tarımsal Araştırmalar Dergisi } \\
\text { dergipark.gov.tr/tutad }\end{array}$ & $\begin{array}{l}\text { Turk J Agric Res } \\
\text { 2018, 5(3): 183-190 } \\
\text { ○) TÜTAD } \\
\text { ISSN: 2148-2306 } \\
\text { e-ISSN: 2528-858X }\end{array}$ \\
\hline 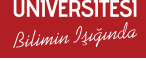 & Araştırma Makalesi / Research Article & $\begin{array}{l}\text { e-ISSN: } 2528-858 X \\
\text { doi: } 10.19159 / \text { tutad.342885 }\end{array}$ \\
\hline
\end{tabular}

\title{
Diyarbakır’da Buğday Ürününe Karışan Yabancı Ot Tohumlarının Belirlenmesi
}

\author{
Fırat PALA ${ }^{\mathbf{1}}$, Hüsrev MENNAN ${ }^{\mathbf{2}}$, Fatih ÇIG ${ }^{3}$, Halil DILMEN $^{1}$ \\ ${ }^{1}$ Siirt Üniversitesi, Ziraat Fakültesi, Bitki Koruma Bölümü, Siirt, TÜRKiYE \\ ${ }^{2}$ Ondokuz Mayls Üniversitesi, Ziraat Fakültesi, Bitki Koruma Bölümü, Samsun, TÜRKiYE \\ ${ }^{3}$ Siirt Üniversitesi, Ziraat Fakültesi, Tarla Bitkileri Bölümü, Siirt, TÜRKIYE
}

\begin{tabular}{|c|c|}
\hline Geliş Tarihi/Received: 11.10 .2017 & Kabul Tarihi/Accepted: 27.07 .2018 \\
\hline \multicolumn{2}{|c|}{ ORCID ID (Yazar surasina göre / by author order) } \\
\hline (1Dorcid.org/0000-0002-4394-8841 (1) orcid.org/0000-0002-14 & id.org/0000-0002-4042-0566 (10) orcid.org/0000-0002-3802-9947 \\
\hline
\end{tabular}

Öz: Bu araştırma hasat edilen buğday ürünü içerisine karışan yabancı ot tohumlarının belirlenmesi amacıyla Diyarbakır ilinde 2017 yılında yapılmıştır. Bu amaçla buğday tarımının yoğun yapıldığı 10 ilçedeki buğday ürünlerinden 100 örnek alınmıștır. Toplanan örnekler eleklerden (6-60 mesh) geçirilmek suretiyle içerisinde bulunan kaba ve cansız materyali alınmış, kalan kısımdaki yabancı ot tohumları ayrılmıştır. Yabancı ot tohumları binoküler mikroskop altında incelenerek tür teşhisleri gerçekleştirilmiştir. Diyarbakır ilinde hasat edilen buğday ürünü içerisine karışan yabancı ot tohumlarının oranı \% 0.51 olduğu tespit edilmiştir. Tespit edilen bu yabanc1 ot tohumları 8 farklı familyadan 28 farklı yabanc1 ot türüdür. Bu yabancı otlardan en fazla karışımın 13 tür ile Poaceae familyasına ait olduğu görülmüştür. En yoğun bulunan yabancı otların Avena fatua ve Avena sterilis olduğu belirlenmiştir. Sonuç olarak, alınan $50.000 \mathrm{~g}$ buğday örneği içerisinde yabancı madde (yabancı ot tohumu+cansız maddeler) karışım miktarı ağırlık olarak $485.3 \mathrm{~g}$ ve karışım oranı ise \% 1.0 olarak tespit edilmiştir. Yabancı ot tohum sayısı 633 adet ve tohum ağırlığı 10.96 gram bulunmuştur. Böylece 2016 yılı için Diyarbakır'da 2.638 .909 da alanda 845.105 ton üretilen buğday ürününe hasatta yaklaşık 8.544 ton yabanc1 ot tohumu ve yabancı madde karıştığı söylenebilir. Buğday içerisinde bulunan yabancı maddenin niteliği ve niceliği buğdayın kalitesini etkileyen kriterlerden birisidir. Yabancı otların öğ̈̈tme değeri olmadığından bunların buğday üretimi esnasında etkili bir şekilde kontrol edilmesi veya öğütme öncesi ayıklanması gıda ve halk sağlığı bakımından önemlidir.

Anahtar Kelimeler: Diyarbakır, buğday, tohum, yabancı ot, safiyet

\section{Determination of Weed Seeds Mixed with Wheat Product in Diyarbakır}

\begin{abstract}
This research was performed to determine the weed seeds that are mixed into the harvested wheat crop in Diyarbakir in 2017. For this purpose, 100 samples were taken from wheat products on 10 provinces wheat cultivated intensively. Collected specimens were passed through sieves (6-60 mesh) and the crude and inanimate material in them was taken and the remaining weed seeds were separated. Weed seeds were examined under the binocular microscope and species identification was carried out. It was determined that the ratio of weed seeds in the wheat mass harvested in Diyarbakır was $0.51 \%$. These weed seeds identified are 28 different weed species from 8 different families. It was found that the most of these weeds belonged to the Poaceae family with 13 species. It was found that the most of these weeds belonged to members of the Poaceae family with 13 species. It had been determined that the most dense weeds were Avena fatua and Avena sterilis. As a result, the amount of impurities (weed seeds + inanimate substances) in the $50.000 \mathrm{~g}$ wheat sample taken was determined as $485.3 \mathrm{~g}$ by weight and the mixing ratio was $1.0 \%$. The number of weed seeds was 633 and the weight of seeds was 10.96 grams. Thus, it can be estimated that about 8.544 tons of weed seeds and impurities are mixed in 845.105 tons wheat produced in Diyarbakir on 2.638.909 da land for the year 2016. The quality and quantity of impurities in wheat is one of the criteria affecting the quality of wheat. Since weeds are not worth milling, it is important that they are controlled effectively during wheat production, or weeding out weeds pre-grinding is important for food and public health.
\end{abstract}

Keywords: Diyarbakır, wheat, seeds, weeds, purity 


\section{Giriș}

Buğday dünyada yaygın olarak yetiştirilen, pek çok ülkenin beslenme ve ticari hayatında önemli rol oynayan, bitkisel ürünler içerisinde en fazla üretimi yapılan ve insan beslenmesinde kullanilan stratejik bir üründür (Arısoy ve Oğuz, 2005). Dünya buğday üretimi yaklaşık 568 milyon ton olup, üretimde ilk sırayı Çin almaktadır. Bu ülkeyi sırasıyla; Hindistan, Rusya, ABD ile Fransa izlemekte ve bu beş ülke dünya buğday üretiminin yarısından fazlası gerçekleştirilmektedir. Türkiye ise yaklaşık 20 milyon tonluk üretim ve \% 3.5'lik pay ile dünya buğday üretiminde sekizinci sırada yer almaktadır (Anonymous, 2014). Türkiye'de 24 milyon hektar alanda tarım yapılmakta, bu alanın yaklaşık 16 milyon hektarında tahıl ekilmekte, bunun da yaklaşık 8 milyon hektarında buğday üretilmektedir. Türkiye'de buğday hemen hemen her bölgede yetiştirilmektedir. Türkiye'nin önemli buğday üretim alanlarından biri olan Güneydoğu Anadolu Bölgesi'nde; üretimin Diyarbakır ilinde yoğunlaştığı, Diyarbakır ili buğday ekim alanı (264 bin ha) bakımından Türkiye'de dördüncü sırada (\% 3.3'lük pay ile), üretim bakımından ise üçüncü sırada (845 bin ton, \% 4.2'lik pay ile) yer almaktadır (Anonim, 2016).

Güneydoğu Anadolu Bölgesi’nde, Güneydoğu Anadolu Projesi (GAP)'nin yakın gelecekte tamamlanmasina paralel olarak 1.8 milyon hektar tarımsal alanın sulamaya açılması ve bu alanlarda sulu buğday üretimine geçilmesi beklenmektedir. $\mathrm{Bu}$ artışla birlikte buğday üretiminde stratejik konumunu daha da güçlendirecek olan bölgede, kaliteyi ve verim miktarını arttırmak hedeflenmektedir. Bu amaçla uygun toprak işleme, yüksek verimli ve kaliteli tohum kullanımı, uygun sulama ve gübreleme gibi verimi arttırıcı tüm tedbirler alınsa dahi; bitki hastalık, zararlı ve yabancı otları ile mücadele yapılmadığı takdirde, tarımsal ürünlerde önemli oranda kayıplar olabileceği rapor edilmiştir (Zimdahl, 2007; Güncan, 2014; Tepe, 2014; Pala ve Mennan, 2017). Buğday üretiminde verim kaybına neden olan yabancı otlar ile mücadele edilmediği takdirde yabancı otlar; bitkinin su, besin maddesi ve 1 şı alımını azaltmakta, verimi ve kalitesinde ekolojik şartlara bağlı olarak dörtte bir oranlarında kayıp oluşturabilmektedir (Uygur ve ark., 1986; Monaco ve ark., 2002). Yabancı otların tür ve genetik çeşitlilik açısından coğrafik bölgelere ve kültür bitkisine, mevsime ve ekim tarihine bağlı olarak büyük çapta farklılık gösterebileceğini belirtmektedirler (Yang ve ark., 2012). Türkiye'de buğday alanlarında önemli bir sorun olan yabancı otların dağılımı ile ilgili yapılan çalışmalar incelendiğinde; Aegilops spp., Agropyron repens (L.) Gould, Agrostemma githago L., Alopecurus myosuroides Huds., Anagallis arvensis L., Anthemis arvensis L., Avena fatua L., Avena sterilis L., Bifora radians Bieb., Boreava orientalis Jaub et Spach., Bromus tectorum L., Capsella bursa-pastoris (L.) Medik., Centaura solstitialis L., Centaurea depressa Bieb., Cephalaria syriaca (L.) Schrad., Chenopodium album L., Consolida orientalis (Gay.) Schröd., Convolvulus arvensis L., Euphorbia helioscopia L., Galium aparine L., Galium tricornutum Dandy., Hordeum spp., Lolium perenne L., Lolium temulentum L., Malva sylvestris L., Matricaria chamomilla L., Papaver rhoeas L., Phalaris paradoxa L., Poa spp., Polygonum aviculare L., Ranunculus repens L., Raphanus raphanistrum L., Secale cereale L., Setaria spp., Sinapis arvensis L., Sonchus spp., Turgenia latifolia (L.) Hoffm., Vaccaria pyramidata Medik., Vicia sativa L., Vicia villosa Roth. türlerinin baskın olduğu görülmektedir (Mennan, 1993; Mennan ve Uygur 1994; Boz, 2000; Boz ve ark., 2000; Tursun, 2002; Üstüner ve Güncan, 2002; Kitiş ve Boz, 2003; Mennan ve Işık, 2003; Gökalp ve Üremiş, 2015; Gürsu, 2015). Yabancı otlar buğdayda verimi etkileyen en önemli unsur olup yabanc1 ot mücadelesi buğday üretiminde önemli bir yer tutmaktadır (Kaya Altop ve ark., 2017).

Buğday ekili alanlarda tespit edilen bu yabanc1 otların bir kısmının hasat edilen buğday ürününe karışması olasıdır. Türkiye'de hasat sonrası buğday ürününe karışan yabancı otlar ile ilgili yapılan çalışmalar incelendiğinde; Adonis aestivalis L., Agrostemma githago L., Avena fatua L., Avena sterilis L., Bifora radians M. Bieb., Bromus spp., Capsella bursa-pastoris (L.) Medik., Convolvulus arvensis L., Hordeum murinum L., Hordeum vulgare L., Galium tricornotum Dandy, Lolium multiflorum Lam., Myagrum perfoliatum, Papaver rhoeas L., Ranunculus arvensis, Sinapis arvensis L., Silybum marianum (L.) Gaert. ve Vicia sativa L. türlerinin yaygın olduğu belirlenmiştir (Tursun ve ark, 2004; Özkil ve Kara 2006; Kordali ve Zengin, 2009; Gökalp ve Üremiş, 2015; Baş ve ark., 2016; Şin ve ark., 2016).

Hasat edilmiş buğday ürünündeki yabancı ot tohumlarının dağılımına bakıldığında ise; Erzurum'da 95 adet yabanc1 ot türünün buğday ürünü içerisindeki karıșım oranının \% 7.21 olduğu (Zengin, 1996); Tokat'ta selektör öncesi yabancı ot tohumlarının karışım oranı \% 2.4 iken, selektör sonrası bu oranın \% 0.4 olarak tespit edildiği (Sırma ve ark., 1997); yine Tokat ilinde yapılan başka bir çalışmada, 16 familyaya ait 49 yabancı ot türünün buğday ürününe karışım oranının ortalama \% 0.57 olduğu (Şin ve ark., 2016); Adıyaman ve Gaziantep'te $1 \mathrm{~kg}$ 'lık buğday ürününde sirasiyla $16.7 \mathrm{~g}$ ve $5.3 \mathrm{~g}$ yabanc1 ot tohumunun belirlendiği 
(Tursun ve ark., 2004); Tekirdağ, Edirne ve Kırklareli'nde buğday ürününde selektörden önce ve sonra sirasiyla $24-15,32-22$ ve $30-25$ arasinda değişen sayıda yabancı ot türü tespit edildiği (Özkil ve Kara, 2006) ve Kahramanmaraş’ta buğday ürününde 32 tür yabanc1 ot türü tohumu olduğu (Tursun ve ark., 2006) rapor edilmiştir.

Güncan (1981)'ın yapmış olduğu araştırmada, Türkiye'de 17 milyon ton hububatla birlikte 204 bin ton yabanc1 ot tohumunun hasat edildiği bildirilmektedir. Koch ve Hurle (1978), tohum temizliği yapılmadığında hububat ürünü içerisinde dörtte bir oranında yabancı ot tohumunun olabileceğini bildirmektedirler. Hasat edilen buğday ürününe karışan yabancı otlar öncelikle tohumluk olarak kullanılacak buğdayda sorun yaratmaktadır. Yabancı otlarla bulaşık tohumluk buğdayın ekilmesi, tarım alanlarına yabancı ot tohumlarının yayılmasına neden olmaktadır. Ayrıca buğday yığınına karışan yabancı ot tohumları ürünün kalitesini de düşürmektedir. Bazı yabanc1 ot tohumlar1 insan ve hayvanlara zehirlidir, bazıları ise un ve unlu mamullerin tat ve aromasını bozmaktadır. Bu durum hasat sonrası buğday ürününe karışan yabancı ot türlerinin ve tohum miktarlarının belirlenmesinin önemli olduğunu göstermektedir.

Buğday ürününe karışan yabancı otlar ile ilgili Türkiye'de çeşitli bölge ve illerde yapılan araştırmalar (Zengin, 1996; Sırma ve ark., 1997; Tursun ve ark, 2004; Özkil ve Kara 2006; Kordali ve Zengin, 2009; Gökalp ve Üremiş, 2015; Baş ve ark., 2016; Şin ve ark., 2016) olmasına rağmen Diyarbakır ilinde herhangi bir çalışmaya rastlanılmamıştır. Bu çalışmada, Diyarbakır ilinde hasat sonrası buğday ürününe karışan yabancı otların belirlenmesi amaçlanmıştır.

\section{Materyal ve Yöntem}

Araştırmaya konu olan Diyarbakır ilinde, Türkiye İstatistik Kurumu (TÜİK) 2016 y1lı verilerine göre (2.638.909 da ve üretimi 845.105 ton üretim ile) yoğun buğday tarımı yapılan; Bağlar, Bismil, Çınar, Dicle, Ergani, Kayapınar, Kocaköy, Silvan, Sur ve Yenişehir ilçelerine bağlı 100 köyden toplam 100 adet numune alınmıştır (Tablo 1). Diyarbakır ilinde bulunan Çermik, Çüngüş, Eğil, Hani, Hazro, Kulp ve Lice ilçelerinde buğday ekimi çok dar alanlarda yapıldığından, bu ilçeler araştırma dışı bırakılmıştır. Örnekler 2017 yılında sonbaharda alınmış, böylece en yeni verilerin elde edilmesine çalışılmıştır. Örnekler tesadüfen seçilmiş köylerden, 1'er kg olarak alınmıştır (Asav ve Kadıoğlu, 2014).

Toplanan örneklerin 75'i ekmeklik buğday olan Saggitario (12 adet), Ceyhan-99 (12 adet),
Yakamoz (10 adet), Vittorio (10 adet), Pehlivan (8 adet), Wafia (7 adet), Pandas (4 adet), Cemre (4 adet), Aldane (2 adet), Selimiye (2 adet), Bereket (2 adet), Dariel (1 adet) ve Yüreğir-89 (1 adet) 'dan; diğer 25'i ise makarnalık buğday çeşitlerinden Sarıbaşak ( 7 adet), Tiziana (6 adet), Cesare (4 adet), Svevo (3 adet), Artuklu (2 adet), Sarıçanak-98 (1 adet), Şahinbey (1 adet) ve Firat93 (1 adet)'ten alınmıştır. Bu buğday çeşitleri ve örnek sayıları Diyarbakır ilinde ekimi yapılan buğday çeşitlerinin oranlarını temsil etmektedir.

Tablo 1. Diyarbakır ilinde alınan örnek miktarları

\begin{tabular}{lcc}
\hline İlçe Adı & Üretim (ton) & Örnek sayısı \\
\hline Bağlar & 27.840 & 3 \\
Bismil & 173.675 & 21 \\
Çınar & 28.436 & 3 \\
Dicle & 25.844 & 5 \\
Ergani & 61.107 & 9 \\
Kayapınar & 26.173 & 3 \\
Kocaköy & 34.540 & 4 \\
Silvan & 161.894 & 3 \\
Sur & 229.150 & 21 \\
Yenişehir & 23.167 & 28 \\
\hline Toplam & 791.826 & 100 \\
\hline
\end{tabular}

Anonim (2016) verilerine göre Diyarbakır ili toplam buğday üretimi 845.105 ton'dur

Araştırmanın ikinci aşamasında, alınan örnekler etiketlenip poşetlere konulduktan sonra, değerlendirmeye alınmak için; ilk olarak Diyarbakır Gida Tarım ve Hayvancılık İl Müdürlüğü’ne, sonra Siirt Üniversitesi Ziraat Fakültesi Bitki Koruma Bölümü Herboloji Laboratuvarı'na götürülmüştür. Laboratuvara getirilen örnekler öncelikle kayıt altına alınmış olup, ardından $1000 \mathrm{~g}$ olacak şekilde hassas terazide tartılarak tüm örnekler eşitlenmiştir. Laboratuvarda örnekler tek tek incelenerek, öncelikle farklı boyutlardaki (6-60 mesh değer aralığındaki) eleklerden geçirilmek sureti ile içerisinde bulunan taş, toprak, saman gibi kaba ve cansız materyal ayıklanmıştır. Elde edilen bu cansız materyal tartılarak alınan her bir örnekteki ağırlıkları tespit edilmiştir. Cansız materyal ayırma işleminden sonra kalan kısımlardan ise 500 g'lık örnekler elde edilmiştir.

Her bir örnekte buğday ürününe karışan yabanc1 ot tohumları sayılarak 100 buğday tanesine karışan tohum sayıları veya 100 g buğday ürününe karışan yabancı ot tohumları el ile ayırma işlemine tabi tutulmuştur. Her bir örnekten elde edilen yabanc1 ot tohumları hassas terazide tartılarak örnek içerisindeki ağırlıkları alınarak hesaplanmıştır. Rastlama sıklı̆̆ 1 ise rastlanan yabancı ot tohumlarının kaç örnekte rastlandığ 1 sayılarak hesaplanmıştır. Araştırmada, yüzde yoğunluk (Y) ve rastlama sıklıkları (R.S.) sırasıyla, 
Eşitlik 1 ve Eşitlik 2 yardımıyla hesaplanmıştır (Odum, 1971; Güncan, 2014).

$$
\begin{aligned}
& \mathrm{Y}(\%)=\mathrm{T} / \mathrm{nx} 100 \\
& \text { R.S. }(\%)=\mathrm{M} / \mathrm{n} \times 100
\end{aligned}
$$

Eşitliklerde, T, alınan örneklerdeki yabancı otun toplam tohum sayısını; N, alınan örnek sayısını ve $M$, yabancı ot türünün rastlandığ 1 örnek sayısını ifade etmektedir.

Baş ve ark. (2016) tarafindan önerilen rastlama sıklığı skalasına göre; çok sık ( $\geq \% 50)$, sık (\% 25$50)$, orta derecede sik ( $\% 10-25)$, nadir "seyrek" olarak bulunan yabancı otlar $(<\% 10)$; ayrica yoğunluk skalasına göre, çok yoğun $(\geq \% 0.06)$, yoğun ( $\% 0.02-0.06)$, orta derecede yoğun (\% 0.01-0.02) ve nadir bulunan yabanc1 ot tohumları $(\leq \% 0.01)$ şeklinde değerlendirilmiştir.

A ğırlıkları belirlendikten sonra yabancı ot tohumları lup ve binoküler mikroskop altında incelenerek, aynı tür olanlar bir arada olacak şekilde gruplandırılmıştır. Gruplandırma işleminden sonra yabancı ot tohumlarının teşhisi için tohum koleksiyonundan ve farklı kaynaklardan yararlanılmıştır (Hanff, 1982; Özer ve ark., 1999; Bojnansky ve Fargasova, 2007; Dickinson ve Boyer, 2014). Yabanc1 otların Türkçe isimleri için Uluğ ve ark. (1993)'ndan istifade edilmiştir. Toplanan örnekler içinde bulunan yabancı ot ve cansız maddelerin karışım oranları, orantı ve aritmetik ortalama hesabına göre Excel'de hesaplanmıştır. Elde edilen veriler JMP 5.0.1 istatistik programında değerlendirilmiş ve sonuçlar LSD testine tabi tutulmuştur.

\section{Bulgular ve Tartışma}

Araştırmada, alınan örnekler içerisinde bulunan yabancı ot tohum miktarı ve karışan diğer yabancı maddelerin ağırlık ve karışım oranları Tablo 2'de verilmiştir.

Tablo 2. Diyarbakır ilinde buğday örneklerinin toplandığg yerlere göre canlı-cansız madde oranları*

\begin{tabular}{lcccc}
\hline İlçe adı & $\begin{array}{c}\text { Numune ağırlı̆̆1 } \\
(\mathrm{g})\end{array}$ & $\begin{array}{c}\text { Canlı madde } \\
\text { karışım oranı }(\%)\end{array}$ & $\begin{array}{c}\text { Cansız madde } \\
\text { karışım oranı }(\%)\end{array}$ & $\begin{array}{c}\text { Yabanc1 ot + cansız madde } \\
\text { karışım oranı }(\%)\end{array}$ \\
\hline Bağlar & 1.500 & $0.48 \mathrm{de}$ & $0.35 \mathrm{e}$ & $0.83 \mathrm{c}$ \\
Bismil & 9.500 & $0.37 \mathrm{~g}$ & $0.28 \mathrm{f}$ & $0.65 \mathrm{~d}$ \\
Çınar & 1.500 & $0.41 \mathrm{fg}$ & $0.32 \mathrm{ef}$ & $0.73 \mathrm{~d}$ \\
Dicle & 2.500 & $0.56 \mathrm{bc}$ & $0.41 \mathrm{~d}$ & $0.97 \mathrm{~b}$ \\
Ergani & 4.500 & $0.45 \mathrm{ef}$ & $0.47 \mathrm{bc}$ & $0.92 \mathrm{bc}$ \\
Kayapınar & 1.500 & $0.49 \mathrm{de}$ & $0.43 \mathrm{~cd}$ & $0.92 \mathrm{bc}$ \\
Kocaköy & 2.000 & $0.54 \mathrm{~cd}$ & $0.40 \mathrm{~d}$ & $0.94 \mathrm{~b}$ \\
Lice & 1.500 & $0.55 \mathrm{c}$ & $0.44 \mathrm{~cd}$ & $0.99 \mathrm{~b}$ \\
Silvan & 9.500 & $0.64 \mathrm{a}$ & $0.51 \mathrm{ab}$ & $1.15 \mathrm{a}$ \\
Sur & 14.000 & $0.62 \mathrm{ab}$ & $0.53 \mathrm{a}$ & $1.15 \mathrm{a}$ \\
\hline LSD & 0.02954 & & & \\
CV $(\%)$ & 1.40412 & & & \\
\hline
\end{tabular}

": Aynı sütunda aynı harfle gösterilen ortalamalar arasındaki farklılık önemli değildir

Diyarbakır ilinde incelenen $50.000 \mathrm{~g}$ buğday numunesi içerisine karışan yabancı otların oranı $\% 0.51$ olarak tespit edilmiştir. Ayrıca \% 0.41 oranında cansız madde olmak üzere toplamda $\% 0.93$ oranında yabancı ot + cansız madde tespit edilmiştir. Diyarbakır'da 1 hasatta buğday ürününe karışan ve yı̆̆ında bulunan önemli bazı yabancı otlar Şekil 1'de görülmektedir. Buğdaya karışan yabanc1 ot tohumları ilçeler bazında karşılaştırıldı ̆̆ında, en fazla Silvan (\% 0.64) ve Sur (\% 0.62) ilçelerinde olduğu tespit edilmiştir (Tablo 2). Diyarbakır ilinde kuru tarımın yapıldığı Silvan ve Sur ilçelerinde hasat sonrası buğday ürününe karışan yabancı ot tohum oranının diğer ilçelere göre yüksek olmasının nedeni, buralarda etkili bir şekilde münavebe yapılmamasıdır. Bu iki ilçede uzun yıllar buğdayın üst üste ekilmesi hem buğday tarım alanlarında kontrol edilemeyen yabancı ot türlerinin hem de hasat edilen buğday ürününe karışan yabancı ot tohum miktarının artmasına neden olmaktadir.

Diyarbakır'da hasat sonrası buğday yı̆̆ını içinde bulunan yabancı ot türleri, rastla sıklıkları, yoğunlukları, tohum sayıları ve ağırlıkları Tablo 3 'te verilmiştir.

Diyarbakır'da buğday ürününe karışan yabancı ot tohumlarından çok sık rastlanılan ve çok yoğun türlerin Avena sterilis (ÇS, \% 52; ÇY, \% 0.0740) ve Avena fatua (CS, \% 51; Y, \% 0.0491) türlerinin olduğu, ayrıca Adonis aestivalis (S, \% 29; Y, $\%$ 0.0278), Galium aparine (S, \% 32; OY, $\% 0.0140)$ ve Ranunculus arvensis (S, \% 28; OY, $\%$ 0.0106) türlerinin s1k görülen türler olduğu belirlenmiştir. Diyarbakır ilinde hasat edilen buğday ürünü içerisine karışan bu yabancı otlar incelendiğinde ise; Diyarbakır'ın farklı toprak ve iklim özellikleri ile uygulanan tarımsal işlemlere 


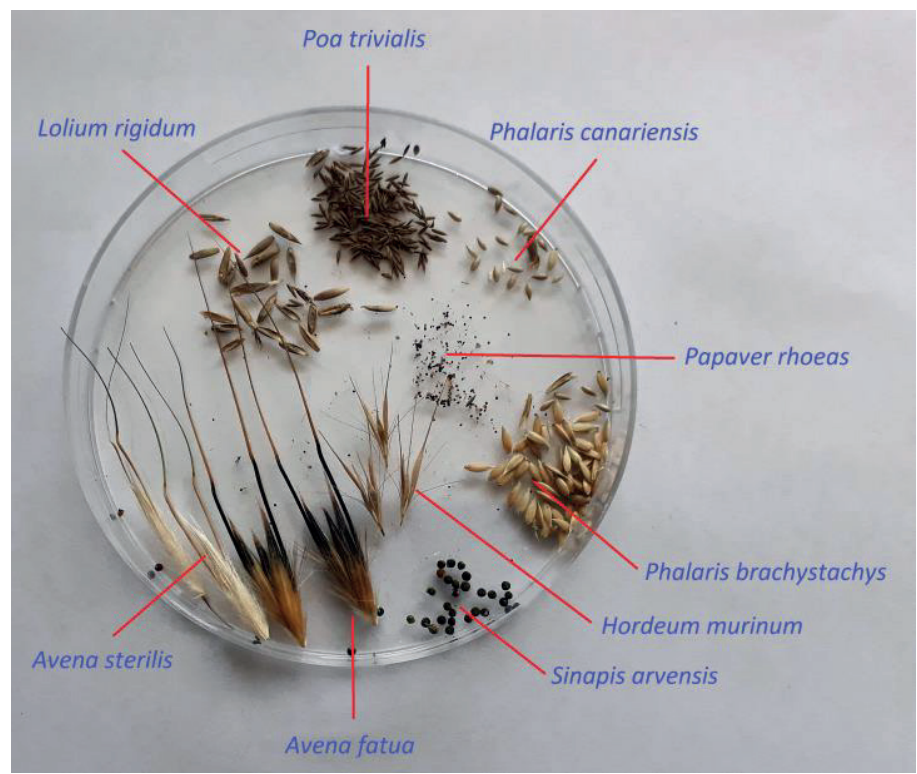

Şekil 1. Hasatta buğday yığınına karışan bazı önemli yabancı ot (Avena fatua, Avena sterilis, Hordeum murinum, Lolium rigidum, Papaver rhoeas, Phalaris branchystachys, Phalaris canariensis, Poa trivialis, Sinapis arvensis) tohumlar1

Tablo 3. Diyarbakır' da 1 kg buğday ürününe karışan yabancı ot tohumları

\begin{tabular}{|c|c|c|c|c|c|c|}
\hline Bilimsel İsmi & Familya & Türkçesi & $\begin{array}{c}\text { *Rastlama } \\
\text { sıklığ } \\
(\%)\end{array}$ & $\begin{array}{c}{ }^{* *} \text { Yoğunluk } \\
(\%)\end{array}$ & $\begin{array}{c}\text { Tohum } \\
\text { sayis1 } \\
\text { (adet) }\end{array}$ & $\begin{array}{l}\text { Tohum } \\
\text { ağırlığ } \\
\text { (g) }\end{array}$ \\
\hline Adonis aestivalis L. & Ranunculaceae & Kandamlas1 & S (29) & $\mathrm{Y}(0.0278)$ & 1.02 & 0.035 \\
\hline Agrostemma githago L. & Caryophyllaceae & Karamuk & $\mathrm{N}(2)$ & $\mathrm{N}(0.0002)$ & 1.78 & 0.036 \\
\hline $\begin{array}{l}\text { Alopecurus myosuroides } \\
\text { Huds. }\end{array}$ & Poaceae & Tilkikuyruğu & $\mathrm{N}(5)$ & $\mathrm{N}(0.0025)$ & 4.16 & 0.010 \\
\hline Avena fatua $\mathrm{L}$. & Poaceae & Yabani yulaf & ÇS (51) & $\mathrm{Y}(0.0491)$ & 86.20 & 2.713 \\
\hline Avena sterilis $\mathrm{L}$. & Poaceae & Kisir yabani yulaf & ÇS (52) & ÇY $(0.0740)$ & 102.64 & 2.986 \\
\hline Bromus tectorum L. & Poaceae & Püsküllü çayır & N (2) & $\mathrm{N}(0.0003)$ & 10.14 & 0.254 \\
\hline $\begin{array}{l}\text { Capsella bursa-pastoris } \\
\text { (L.) Medik. }\end{array}$ & Brassicaceae & Çobançantası & $\mathrm{N}(1)$ & $\mathrm{N}(0.0001)$ & 1.05 & 0.002 \\
\hline Centaurea depressa Bieb. & Asteraceae & Gökbaş & OS (12) & $\mathrm{N}(0.0035)$ & 2.15 & 0.064 \\
\hline Cirsium arvense (L.) Scop. & Asteraceae & Köy göçüren & OS ( & OY $(C$ & 7.04 & 0.088 \\
\hline Daucus carota L. & Apiaceae & Yabani havuç & $\mathrm{N}($ & $\mathrm{N}(0.0$ & 3.00 & 0.009 \\
\hline Galium aparine L. & Rubiaceae & Dil kanatan & S (32) & OY $(0.0$ & 51.82 & 0.376 \\
\hline Galium tricornutum Dandy & Rubiaceae & Yoğurt otu & OS (13) & $\mathrm{N}(0.0066)$ & 4.66 & 0.029 \\
\hline Hordeum murinum L. & Poaceae & Duvar arpas1 & OS (16) & $\mathrm{N}(0.0095)$ & 18.69 & 0.461 \\
\hline Hordeum vulgare L. & Poaceae & Kendi gelen arpa & $\mathrm{N}(7)$ & $\mathrm{N}(0.0046)$ & 19.45 & 0.873 \\
\hline Lolium rigidum Guad. & Poaceae & İnce delice & $\mathrm{N}(3)$ & $\mathrm{N}(0.0018)$ & 10.28 & 0.678 \\
\hline Myagrum perfoliatum L. & Brassicaceae & Gönül hardalı & $\mathrm{N}(2)$ & $\mathrm{N}(0.0004)$ & 1.54 & 0.025 \\
\hline Papaver rhoeas L. & Papaveraceae & Gelincik & OS (10) & OY $(0.0125)$ & 1.25 & 0.002 \\
\hline Phalaris brachystachys L. & Poaceae & Kuşyemi & OS (12) & OY (0.0107) & 9.16 & 0.043 \\
\hline Phalaris canariensis L. & Poaceae & $\begin{array}{l}\text { Uzun başlikl1 } \\
\text { kuşyemi }\end{array}$ & OS (14) & $\mathrm{N}(0.0085)$ & 13.45 & 0.061 \\
\hline Poa pratensis L. & Poaceae & Çayır salkım otu & $\mathrm{N}(1)$ & & 0.56 & 0.001 \\
\hline Poa trivialis $\mathrm{L}$. & Poaceae & Adi salkım otu & $\mathrm{N}(5)$ & $\mathrm{N}(0.003$ & 5.23 & 0.006 \\
\hline Ranunculus arvensis L. & Ranunculaceae & Tarla düğün çiçeği & S (28) & OY $(0.0106)$ & 35.26 & 1.044 \\
\hline Scandix pecten-veneris L. & Apiaceae & Zühre tarağ1 & $\mathrm{N}(1)$ & $\mathrm{N}(0.0001)$ & 1.00 & 0.001 \\
\hline Senecio vulgaris L. & Asteraceae & Kanarya otu & $\mathrm{N}(2)$ & $\mathrm{N}(0.0002)$ & 2.75 & 0.001 \\
\hline Sinapis arvensis L. & Brassicaceae & Yabani hardal & $\mathrm{N}(7)$ & $\mathrm{N}(0.0013)$ & 96.12 & 0.455 \\
\hline Triticum durum L. & Poaceae & Makarnalık buğday & OS (21) & $\mathrm{N}(0.0056)$ & 73.10 & 0.465 \\
\hline Trtiticum aestivum L. & Poaceae & Ekmeklik buğday & OS (20) & $\mathrm{N}(0.0055)$ & 35.20 & 0.219 \\
\hline $\begin{array}{l}\text { Vaccaria pyramidata } \\
\text { Medik. }\end{array}$ & Caryophyllaceae & Arap baklas1 & $\mathrm{N}(4)$ & $\mathrm{N}(0.0008)$ & 4.63 & 0.022 \\
\hline
\end{tabular}

": Rastlama sıklı̆̆ı skalasına göre; çok sık (ÇS $\geq \% 50)$, sık ( $\mathrm{S}=\%$ 25-50), orta derecede sık $(\mathrm{OS}=\%$ 10-25), nadir olarak bulunan yabancı otlar $(\mathrm{N}<\%$ $10),{ }^{* *}$ : Yoğunluk skalasına göre; çok yoğun $(C ̧ Y \geq \% 0.06)$, yoğun $(\mathrm{Y}=\% 0.02-0.06)$, orta derecede yoğun (OY=\% $\left.0.01-0.02\right)$ ve nadir bulunan yabanc1 ot tohumları $(\mathrm{N} \leq \% 0.01)$ 
bağlı olarak 8 farklı familyadan, 28 farklı yabancı ot türünün tohumu tespit edilmiştir. En çok karışımın 13 tür ile Poaceae familyasına ait olduğu görülmüştür.

Şin ve ark. (2016)'nın Tokat ilinde belirlediği yabancı otların oranının (\% 0.57$)$ ve dağılımının (16 familyaya ait 49 tür) Diyarbakır'dan (\% 0.51 ve 8 familyaya ait 28 tür) daha fazla olduğu görülmüştür. Kordali ve Zengin (2009)'in Bayburt ilinde farklı kültür bitkilerinde 18 familyaya ait 65 adet yabancı ot türü içerisinde en çok karşılaşılan yabancı otların, Avena fatua, Hordeum vulgare ve Lolium multiflorum olduğu yönündeki bulguları tespitlerimiz ile benzerlik göstermektedir. Ancak buğday tohumundaki yabancı ot oranı (\% 0.44$)$, bizim sonuçlarımızdan $\left(\begin{array}{lll}\% & 0.51\end{array}\right)$ düşük bulunmuştur. Tokat, Bayburt ve Mardin ilinde yapılan çalışmalarda buğday ürününe en fazla karışan yabancı otlar Diyarbakır ilinde olduğu gibi Poaceae familyasına ait bulunmuştur (Kordali ve Zengin, 2009; Gökalp ve Üremiş, 2015; Baş ve ark., 2016; Şin ve ark., 2016).

Geçmiş yıllarda hasat edilen buğday yı̆̆ınlarında yabancı ot tohumlarının daha fazla olduğu (Erzurum, \% 2.04) bilinmektedir (Zengin, 1996). Sırma ve ark. (1997)'nın Tokat'ta buğdayda selektör öncesi ve sonrası yabanc1 ot tohum oranlarının \% 2.41 ve \% 0.44 olduğunu, selektörün önemli düzeyde yabancı ot tohumunu azalttığını bildirmiștir. Tepe (1998), Van'da bu oranı \% 12.11 oranında tespit etmiştir. Birbirine yakın dönemde yapılan bu çalışmalar göstermiştir ki, buğday içerisine karışan yabancı ot yoğunluğu farklı bölgelerde değişkenlik göstermektedir. Ancak, Samsun ilinde 349 buğday örneğinde 11 farklı familyaya ait 18 yabancı ot türü içindeki Galium aparine, Ranunculus repens ve Avena fatua (Mennan ve Işık, 2003) Diyarbakır ilinde de görülmüştür.

Tursun ve ark. (2004)'nın bölgemizde bulunan Adiyaman (16.7 g) ve Gaziantep (15.3 g) illerinden aldıkları 1 kg'lık buğday örneği içerisinde belirledikleri yabancı ot tohumlarının yoğunluğu, Diyarbakır'dan (11.0 g) fazla olduğu görülmüştür. $\mathrm{Bu}$ durum son yıllarda hem Diyarbakır'da sertifikalı buğday üretiminin ve kullanımın yaygınlaştığının hem de ürünün hassas biçerdöverle hasat edildiğinin bir göstergesidir. Ayrıca söz konusu araştırmacılar Adıyaman'da 23, Gaziantep'te ise 32 tür yabanc1 ot tohumu tespit etmişler; en fazla yabanc1 ot tohumunun $S$. arvensis'e ait olduğunu belirlemişlerdir. Tursun ve ark. (2006) tarafından Kahramanmaraş'ta yapılan çalışmada ise 32 tür yabancı ot tohumu ve bunlar içerisinde de en yoğun olarak $H$. vulgare, $S$. arvensis ve $G$. temulentum'un türleri bulunmuştur.
Adıyaman, Gaziantep ve Kahramanmaraş illerinde belirlenen yabancı ot tohumlarının büyük bir kısmının Diyarbakır'da da bulunması bazı yabancı otlarının bu illerden tohumluk olarak getirilen buğday ile de gelmiş olabileceği kanısını uyandırmıştır.

Baş ve ark. (2016) tarafindan yapılan çalışmada Bayburt ve Gümüşhane illerinden 50 köyden 117 numune alınmış, alınan buğday örnekleri içerisinde 17 familyaya ait 47 yabancı ot türü tohumu tespit edilmiştir. Bu türler içerisinde ise Agrostemma githago ve Caucalis latifolia çok yoğun olarak bulunmuştur. $A$. githago yaptığımız çalışmalarda Diyarbakır'da az yoğunlukta bulunmuş, $C$. latifolia'ya rastlanmamıştır. $\mathrm{Bu}$ durum, farklı bölgelerdeki değişik iklim ve toprak yapısının hasat edilen buğday ürününe karışan yabanc1 ot türlerine etkisinden kaynaklanmış olabileceği düşünülmektedir.

Pala ve Mennan (2017), Diyarbakır ilinde buğday tarlalarında 26 familyaya ait 107 yabanc1 ot türünü tespit etmişler ve $A$. fatua, $S$. arvensis, $R$. arvensis, $G$. aparine ve $C$. arvense türlerininin yoğun olduğunu bildirmişlerdir. Diyarbakır ilinde buğday tarlalarında yoğun olarak görülen yabancı ot tohumlarının bir kısmının hasat edilen buğday ürününe karıştığ1 görülmüştür. Capsella bursapastoris, G. tricornutum, Sinapis arvensis ve Papaver rhoeas hasat sirasinda tohumunu az döktüğü için (Özer ve ark., 2003) bu türlerin tohumları daha çok ürüne karışmış, ancak Ranunculus arvensis dikenli olduğu için daha az karıştığ1 belirlenmiştir. Tarla döneminde diğer yaygın ve yoğun olarak görülen bazı yabancı ot tohumlarının ise hasat sırasında tarlaya çok dökülmesi veya iri tohum kapsülleri veya yapıları nedeni ile buğday ürünü içerisine az yoğunlukta karıştığ 1 tahmin edilmektedir.

Asav ve Kadıŏlu (2014)'nun yapmış oldukları çalışmaya göre, Rusya'dan ithal edilen buğdayı taşıan 12 adet gemiden 50 kg'llk örnekler alınmış, çalışma sonucunda 19 farklı familyaya ait 68 yabanc1 ot türü tespit edilmiştir. $\mathrm{Bu}$ durum, Türkiye'de ürüne karışan bazı yabancı ot tohumlarının ithal edilen ürünlerle taşınabilmiş olabileceğine işaret etmektedir.

Diyarbakır ilinde buğday ürününe karışan Adonis aestivalis, Agrostemma githago, Cirsium arvense, Lolium spp., Papaver rhoeas, Senecio vulgaris ve Sinapis arvensis tohumlarından değişik kaynaklarda insan ve hayvanlara zehirli olduğu bildirilmiştir (Watt ve ark., 1962; Seçmen ve Leblebici, 1987; Picon ve ark., 1991; Suter, 2002; Wagstaff, 2008; Anonim, 2017). Bu zehirli yabancı otların içerdiği alkoloidler alerjik 
reaksiyonlara neden olarak insan sağlığını tehdit edebilmektedir.

Diyarbakır ilinde hasat edilen buğday ürünü içerisindeki yabancı ot tohumlarının ve cansız yabanc1 maddelerin miktar olarak belirlenmesi ve yabancı ot tohumlarının teşhis edilmesi amaciyla yapılan bu çalışmada yoğun ve yaygın bir yabancı ot tohum popülasyonu belirlenmiştir.

Diyarbakır'ın 10 ilçesinden toplam $50.000 \mathrm{~g}$ buğday içerisinde yabancı madde (yabancı ot tohumu+cansız maddeler) karışım miktarı ağırlık olarak $485.3 \mathrm{~g}$, karışım oranı ise \% 1.0 olarak tespit edilmiştir. Diyarbakır'da 2016 yılında 2.638.909 da alanda 845.105 ton üretilen buğday ürününe hasatta 8.544 ton yabancı ot tohumu ve yabancı madde karıştığı hesaplanabilir. Bu miktar yabancı ot tohumu açısından değerlendirildiğinde Güncan (1981)'ın bulgularından daha azdır. Bunun nedeni olarak buğday ekim alanlarında yabancı ot mücadelesindeki ve mekanizasyondaki teknolojik gelişmeler olduğu düşünülmektedir.

\section{Sonuçlar}

Buğday ürünü içerisindeki yabancı maddeler önemli ölçüde kalite kaybına neden olabilecektir. Ayrıca zehirli yabancı ot tohumları miktara bağlı olarak insan sağlığını olumsuz etkileyebilir.

Buğday alanlarında sorun olan yabancı otların kontrolü için kültürel uygulamalar (sertifikalı tohumluk kullanmak, münavebe uygulamak), mekanik uygulamalar (pullukla derin sürüm, ekim öncesi yağıştan sonra çimlenen yabancı otlar sürümle yok edildikten sonra ekim yapmak) ve kimyasal mücadele (uygun herbisitin, uygun zamanda, uygun dozda ve uygun aletle uygulanmas1) entegre bir şekilde yürütülmelidir.

Hasat edilen buğdayın bir kısmı insanların ana beslenme kaynağı olan un ve unlu mamuller için sanayide kullanılmaktadır. Buralarda kullanılacak buğday ürünü içindeki yabancı otların ve diğer zararlı maddelerin ayıklanması insan sağlığının korunması için önem arz etmektedir. Bu çalışma hasat sonrası tarlada veya depodaki yığın halinde olan buğday ürünündeki yabanc1 otlara odaklanmıştır. $\mathrm{Bu}$ çalışmanın genişletilerek buğday işleme tesislerinde buğdayın gida ürünlerine dönüştürülmeden önceki ham buğday ürününde de yapılmasının halk sağlığını korumak için önemli olduğu kanısı hasıl olmuştur. Buna ek olarak tohumluk işleme tesislerinde korteks ve hassas sensörlü elek kullanımının yaygınlaştırılmasının hasat sonrası buğday ürününe karışan yabancı otlar ve diğer cansız maddelerin temizlenmesi ve saf tohumluk üretimi için önemli olduğu sonucuna varılmıştır.

\section{Kaynaklar}

Anonim, 2016. Bitkisel Üretim. https://biruni.tuik.gov.tr/ bitkiselapp/bitkisel.zul. (Erişim tarihi: 16.05.2017).

Anonim, 2017. Zehirli Yabanc1 Otlar. http:// www.turkiyeherboloji.org.tr/otlar.asp?tur=6. (Erişim tarihi: 24.07.2017).

Anonymous, 2014. Crop Production Data. http:// www.fao.org/faostat/en/\#data. (Erișim tarihi: 01.04.2017).

Arısoy, H., Oğuz, C., 2005. Tarımsal araştırma enstitüleri tarafindan yeni geliştirilen buğday çeşitlerinin tarım işletmelerinde kullanım düzeyi ve geleneksel çeşitler ile karşılaştırmalı ekonomik analizi: Konya ili örneği. Yüksek lisans tezi, Selçuk Üniversitesi, Fen Bilimleri Enstitüsü, Konya.

Asav, Ü., Kadıŏlu, İ., 2014. Rusya Fedarasyonu'ndan Türkiye'ye ithal edilmek üzere Trabzon Limanı'na gelen buğdaylardaki yabancı ot tohumlarının belirlenmesi. Iğdır Üniversitesi Fen Bilimleri Enstitüsü Dergisi, 4(4): 29-36.

Baş, A., Karaca, M., Güncan, A., 2016. Doğu Karadeniz Bölgesi'nde buğday ürününe karışan yabancı ot tohumlarının tespiti ve dağılışları. Turkish Journal of Weed Science, 19(2): 49-60.

Bojnansky, V., Fargasova, A., 2007. Atlas of seeds and fruits of Central and East-European flora, The Carpathian Mountains Region, Netherlands.

Boz, Ö., 2000. Aydın ili buğday ekim alanlarında bulunan yabanc1 otlar ile rastlama siklikları ve yoğunluklarının saptanması. Türkiye Herboloji Dergisi, 3(2): 1-11.

Boz, Ö., Doğan, M.N., Dura, S., 2000. Denizli ili buğday ekim alanlarındaki yabancı otların yaygınlık ve yoğunluklarının saptanması. Türkiye Herboloji Dergisi, 3(1): 37-52.

Dickinson, R., Boyer, F., 2014. Weeds of North America. The University of Chicago Press, Chicago, IL.

Gökalp, Ö., Üremiş, İ., 2015. Mardin'de buğday ürününe karışan yabancı ot tohumlarının belirlenmesi. Mustafa Kemal Üniversitesi Ziraat Fakültesi Dergisi, 20(1): 23-30.

Güncan, A., 1981. Anadolu'nun doğusunda buğday ürününe karışan yabancı ot tohumları, yoğunlukları ve önemlilerinin oluşturdukları bitki toplulukları (Assosiation) üzerine bir araștırma. Atatürk Üniversitesi Ziraat Fakültesi Dergisi, Erzurum.

Güncan, A., 2014. Yabancı Ot Mücadelesi. Selçuk Üniversitesi Yayınevi, Konya.

Gürsu, Z., 2015. Kırklareli ili buğday ekim alanlarında görülen önemli yabancı ot türleri, yoğunlukları ve rastlanma sıklıklarının belirlenmesi. Yüksek lisans tezi, Namık Kemal Üniversitesi, Fen Bilimleri Enstitüsü, Tekirdağ.

Hanff, M., 1982. The Arable Weeds of Europe. BASF United Kingdom Limited, Lady Lane, Hadleigh, Suffolk.

Kaya Altop, E., Mennan, H., Işık, D., 2017. Buğday ekim alanlarında sorun olan Bifora radians Bieb. 
(Kokarot)'in ALS inhibitörü herbisitlere dayanıklılığının PCR temelli olarak belirlenmesi. Anadolu Tarm Bilimleri Dergisi, 32(2): 153-163.

Kitiş, Y.E., Boz, Ö., 2003. Isparta ili buğday ekim alanlarındaki yabanc1 otların yaygınlık ve yoğunluklarının saptanması. Türkiye Herboloji Dergisi, 6(1): 24-25.

Koch, W., Hurle, K., 1978. Grundlagen der Ukrautbekampfung, Verlag Eugen Ulmer, Stutart.

Kordali, Ş., Zengin, H., 2009. Bayburt ilinde arpa, buğday ve mercimek tohumluklarındaki yabancı ot türlerinin belirlenmesi. Atatürk Üniversitesi Ziraat Fakültesi Dergisi, 40(2): 43-55.

Mennan, H., 1993. Samsun ili buğday ekim alanlarında görülen yabancı ot türlerinin belirlenmesi ve önemli türlerin çimlenme ve gelişme biyolojilerinin araştırılması. Yüksek lisans tezi, Çukurova Üniversitesi, Fen Bilimleri Enstitüsü, Adana

Mennan, H., Işık, D., 2003. Buğday tohumluğunda bulunan yabancı ot tohumlarının yoğunlukları ve bitkiye dönüşüm oranlarının saptanması. Türkiye Herboloji Dergisi, 6(1): 8-15.

Mennan, H., Uygur, F.N., 1994. Samsun ili buğday ekim alanlarında görülen yabancı otların saptanması. Ondokuz Mayls Üniversitesi Ziraat Fakültesi Dergisi, 9(2): 25- 35.

Monaco, T.J., Weller, S.C., Ashton, F.M., 2002. Weed Science-Principles and Practices. Johnwiley \& Sons, Inc, 4th ed., New York.

Odum, E.P., 1971. Fundamentals of Ecology. W. B. Saunders Company, Philadeiphia, London, Toronto, $574 \mathrm{p}$.

Özer, Z., Kadığlu, İ., Önen, H., Tursun, N., 2003. Herboloji (Yabanc1 Ot Bilimi). Gaziosmanpaşa Üniversitesi Ziraat Fakültesi Yayınları No: 20, Kitaplar Serisi No: 10, Genişletilmiş 3. Bask1, Tokat.

Özer, Z., Önen, H., Tursun, N., Uygur, F.N., 1999. Türkiye'nin Bazı Önemli Yabancı Otları (Tanımları ve Kimyasal Savaşımları). Gaziosmanpaşa Üniversitesi Ziraat Fakültesi Yayınları No: 38, Kitap Serisi No: 16, Tokat.

Özkil, M., Kara, A., 2006. Trakya bölgesinde selektörden önce ve sonra buğday ürününe karışan yabancı ot tohumlarının ve yoğunluklarının belirlenmesi. Trakya Üniversitesi Fen Bilimleri Dergisi, 7(1): 45-52.

Pala, F., Mennan, H., 2017. Diyarbakır ili buğday tarlalarında bulunan yabanc1 otların belirlenmesi. Bitki Koruma Bülteni, 57(4): 447-461.

Picon, S.J., Blanco Carmona, J.G., Garces Sotilis, M.D., 1991. Occupational asthma caused by vetch (Vicia sativa). The Journal of Allergy and Clinical Immunolgy, 88(1): 135-136.

Seçmen, Ö., Leblebici, E., 1987. Yurdumuzun Zehirli Bitkileri. Ege Üniversitesi Fen Fakültesi Baskı İşleri, İzmir.

Sırma, M., Kadığlu, İ., Güncan, A., 1997. Tokat ve yöresinde tohumluk buğdayda selektörden önce ve sonra ürüne karışan yabancı ot tohumlarının ve yoğunluklarının belirlenmesi. Türkiye II. Herboloji Kongresi, 1-4 Eylül, Ayvalık-Balıkesir, s. 279-287.

Suter, R.J., 2002. Suspected cyanide poisoning in cows fed vetch (Vicia sativa) hay. Australian Veterinary Journal, 80(5): 282.

Şin, B., Kadıŏlu, İ., Kamışlı, B., 2016. Tokat ilinde buğday ürünü içerisine karışan yabanc1 ot tohumlarının belirlenmesi. Turkish Journal of Weed Science, 19(2): 28-37.

Tepe, I., 1998. Van'da buğday ürününe karışan yabancı ot tohumlarının yoğunluk ve dağılımları. Türkiye Herboloji Dergisi, 1(2): 1-13.

Tepe, I., 2014. Yabancı Otlarla Mücadele. Sidas Medya Ziraat Yayın No: 031, İzmir.

Tursun, N., 2002. Kahramanmaraş ili ve ilçelerinde buğday ekim alanlarında sorun olan yabancı otların belirlenmesi. Türkiye Herboloji Dergisi, 5(1): 1-11.

Tursun, N., Kantarc1, Z., Seyithanoğlu, M., 2004. Adıyaman ve Gaziantep bölgelerinde buğday ürününe karışan yabancı ot tohumlarının belirlenmesi. Türkiye Herboloji Dergisi, 7(1): 1-12.

Tursun, N., Kantarc1, Z., Seyithanoğlu, M., 2006. Kahramanmaraş’ta buğday ürününe karışan yabancı ot tohumlarının belirlenmesi. Kahramanmaras Sütçü Imam Üniversitesi Fen ve Mühendislik Dergisi, 9(2): 110-115.

Uluğ, E., Kadığlu, İ., Üremiş, İ., 1993. Türkiye'nin Yabancı Otları ve Bazı Özellikleri. T.C. Tarım ve Köyişleri Bakanlığı Zirai Mücadele Araştırma Enstitüsü Müdürlüğü, Yayın No: 78, Adana.

Uygur, F.N., Koch, W., Walter, H., 1986. Çukurova Bölgesi Buğday-Pamuk Ekim Sisteminde Önemli Yabancı Otların Tanımı, PLTS 4(1). Josef Margraf, Aichtal.

Üstüner, T., Güncan, A., 2002. A Research on weed species which are problem, importance, biology of germination and control possibilties of them in potato fields in Nigde province. Ph. D Thesis, Department of Plant Protection, Selcuk University, Konya, Turkey.

Wagstaff, D.J., 2008. International Poisonous Plant Checklist: An Evidence-Based Reference. CRC Press, Taylor \& Franchis Group, New York.

Watt, J.M., Gerdina, M., Brandwijk, B., 1962. Medicinal and Poisonous Plants of Southern and Eastern Africa. E. and S. Livinstone Ltd., London, pp. 173175.

Yang, J., Tang, L., Guan Y.L., Sun, W.B., 2012. Genetic diversity of an alien 1nvasive plant mexican sunflower (Tithonia diversifolia) in China. Weed Science, 60(4): 552-557.

Zengin, H., 1996. Erzurum ve ilçelerinde yazlık buğday ürününe karışan yabancı ot tohumları ve yoğunlukları üzerine araştırmalar. Atatürk Üniversitesi Ziraat Fakültesi Dergisi, 27(3): 411422.

Zimdahl, R.L., 2007. Fundamentals of Weed Science. Academic Press in an Imprint of Elsiver, 3rd ed., Burlington, MA. 